\title{
6. SITE SURVEY RESULTS AT THE MOUTH OF THE GULF OF CALIFORNIA, LEG 65, DEEP SEA DRILLING PROJECT ${ }^{1}$
}

B. T. R. Lewis, School of Oceanography, University of Washington, Seattle, Washington

W. E. Snydsman, Union Oil Corporation, Los Angeles, California

J. S. McClain, University of California, Davis, California

M. L. Holmes, U.S. Geological Survey, Seattle, Washington

and

C. R. B. Lister, School of Oceanography, University of Washington, Seattle, Washington

\begin{abstract}
During an IPOD site survey at the mouth of the Gulf of California, an axial valley about $50 \mathrm{~km}$ long and 600 meters deep was found on the East Pacific Rise (EPR) south of the Tamayo Fracture Zone. Magnetic anomalies along the axis of the rise change character from the axial valley to normal sections of the EPR, and off-axis anomalies tend to meander slightly with age, probably indicating that the axial injection zone wanders slightly with time. Along the Baja California margin the magnetic lineations cut across the bathymetric expression of the margin, suggesting that the original rifting of Baja from the mainland occurred along a roughly linear zone. A decrease of heat flow and an increase in sediment thickness and water depth with age from 0 to $3.5 \mathrm{~m}$.y. are consistent with concepts of plate tectonics.

Seismic refraction data across and adjacent to the axis of spreading suggest the presence of low-velocity material under the axis, possibly the result of a magma chamber, and a crust which thickens rapidly away from the axis.
\end{abstract}

\section{INTRODUCTION}

\section{Site Survey Objectives}

The principal objectives of the site survey for the International Phase of Ocean Drilling (IPOD) in the Gulf of California were to survey and locate sites for (1) a deep drill hole as close to the axis of the East Pacific Rise (EPR) as possible, and (2) a series of holes crossing a passive continental margin, in this case the margin at the tip of Baja California.

The first objective was recommended by the JOIDES Ocean Crust Panel. In particular, it was desired that a hole be drilled in as young crust as possible so that the chemistry, petrology, magnetic properties, and mechanisms of water circulation in the crust could be studied shortly after its formation. Ridge crests are by definition very young and lack sediment, and yet a technical requirement of the site was that there be sufficient sediment (about $100 \mathrm{~m}$ ) to spud the hole. These competing goals dictated that the site be close to a source of sediment, which is why the Gulf of California was selected.

The second objective of the site survey was recommended by the Passive Margin Panel, which desired to drill holes in both the oceanic and continental crust in order to look at a young passive margin in terms of the changes in rock type across the margin and the mechanism of rifting that created the margin. The mouth of the Gulf of California satisfies these requirements since the continental margin at the tip of Baja California was created about 3.5 million years (m.y.) ago, when Baja

\footnotetext{
I'Lewis, B. T. R., Robinson, P., et al., Init. Repts. DSDP, 65: Washington (U.S. Govt. Printing Office).
}

California was rafted away from mainland Mexico. It is now a passive margin where no subduction or obduction is occurring. Figure 1 shows the general location of the area.

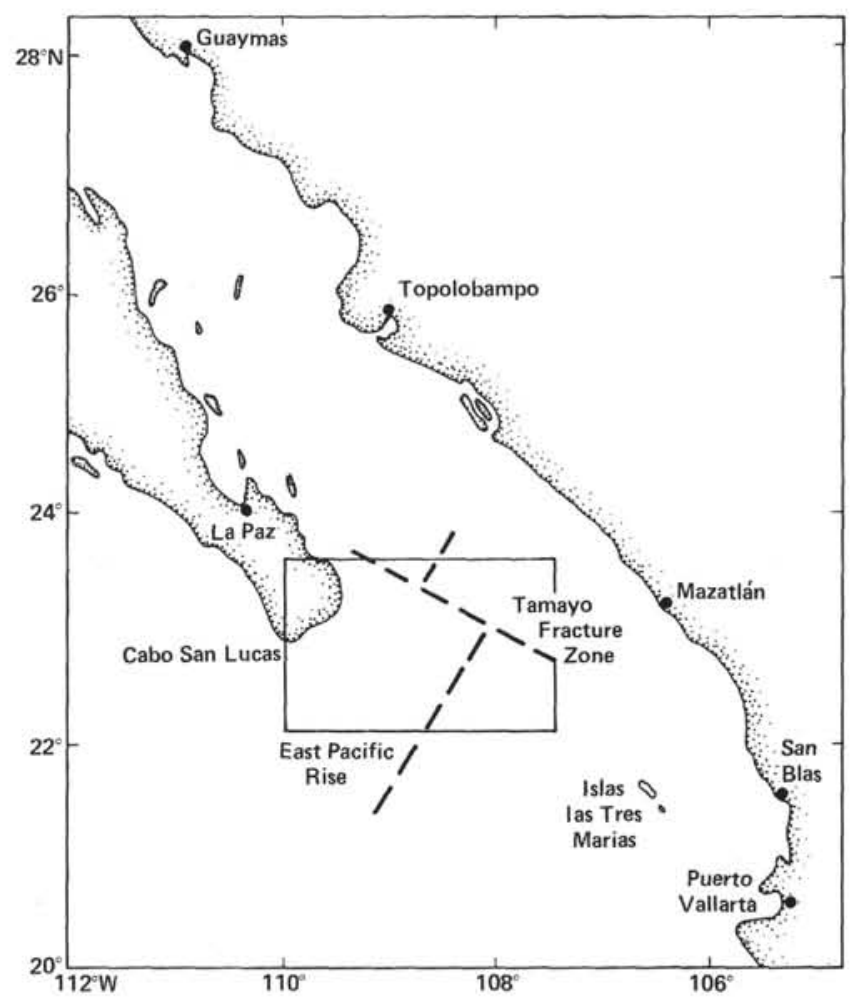

Figure 1. Location of survey area showing East Pacific Rise and Tamayo Fracture Zone. 
For the ridge crest site, the specific objectives were as follows: (1) to locate and define the rise axis accurately, (2) to locate suitable sediment ponds for drilling, (3) to date the structures found, using magnetic anomalies, (4) to obtain representative core and dredge samples, (5) to measure heat flow, and (6) to undertake seismic refraction experiments using ocean-bottom seismometer (OBS) techniques to define the crustal velocity structure for later comparison with the results of drilling.

For the margin sites, the major objectives were to define the margin and the location of the initial rupture, and to use seismic refraction methods to investigate and define differences between the oceanic crust and continental crust.

Since these potential sites were relatively close together $(120 \mathrm{~km})$, it was decided to combine the surveys. This appears to have been an advantageous procedure since a coherent picture extending from the ridge to the margin was obtained.

\section{Previous Studies}

Parts of the Gulf of California have been quite thoroughly studied, and a comprehensive compilation of papers on the area was edited by van Andel and Shor and published in 1964 by the American Association of Petroleum Geologists. These papers covered geophysical, geological, paleontological, zoological, and physical oceanographic topics. Subsequently, Normark and Curray (1968) published a detailed description of the geology and structure of the tip of Baja California, Larsen (1972) used magnetic anomaly data to discuss the plate tectonic history of the mouth of the Gulf of California, Molnar (1973) derived fault plane solutions for earthquakes occurring in the Gulf, and Moore (1973) discussed geologic evidence for plate edge deformation in the Gulf of California.

The results we obtained from our detailed site survey during 1975 were, however, substantially different from those acquired in the course of the earlier studies, a fact which emphasizes the importance of pre-drilling site surveys.

\section{DESCRIPTION OF DATA}

\section{Navigation}

The prime instrument for gathering navigation information was a Magnavox satellite system; normal deadreckoning procedures were used to establish positions between satellite fixes. Except for a few lines the entire survey was run at 6 knots.

During the execution of the seismic refraction lines, a moored telemetering seismic buoy equipped with a radar transponder and reflector was used for detailed navigation. Figure 2 shows the track lines and sampling stations.

\section{Bathymetry and Seismic Reflection Profiling}

A Raytheon $12 \mathrm{kHz}$ echo sounder was the prime source of bathymetric data. The depth was recorded every five minutes, or about every kilometer, and a bathymetric contour chart (Fig. 3) was constructed from these data and any other available data, assuming an average water velocity of $1460 \mathrm{~m} / \mathrm{s}$.

A Lister electromagnetic attraction transducer was used for seismic profiling and a 40 in. ${ }^{3}$ air-gun system was used as a backup. The Lister system has its peak output at $200 \mathrm{~Hz}$ and gives better resolution than the air-gun system but slightly less penetration. Reflection gear was towed on most lines, including the refraction shooting lines, so that good coverage of the sediment thickness was obtained and accurate corrections to the refraction data could be made. Selected reflection records are shown in Figure 4, and a contour chart of sediment thickness in the survey area is shown in Figure 5.

\section{Magnetics}

A proton-precession magnetometer was used to measure the total magnetic field strength. No corrections for diurnal variations or magnetic storms were made, but the data do not seem to contain any peculiarities that might be attributable to such events. The data were sampled once a minute, or about every 200 meters, but were only digitized to one sample per five minutes since the high-frequency variations recorded at the sea surface are commonly small. The International Geomagnetic Reference Field over the survey area is essentially constant, so an average value was subtracted from each line to determine the magnetic anomaly. Figure 6 shows selected magnetic anomaly profiles over the survey area.

\section{Station Operations}

A total of 16 stations were occupied during the survey to collect heat-flow measurements, gravity cores, and dredge haul samples. The locations of the stations are shown in Figure 2. The stations were numbered in consecutive order, with a two-letter modifier denoting the type of operation: HF-heat flow, GC-gravity core, DH-dredge haul.

\section{Heat Flow}

Nine heat-flow stations were attempted using a Bullard-type probe (Lister, 1970). Five of the stations yielded usable gradient and conductivity measurements, while one station gave only gradient information. The locations of these stations are shown in Figure 2 and the results are summarized in Table 1. One heat-flow station (HF-05) was made near Site 482; a second (HF-13) was made near Site 483 along Line 6, and four other stations were made along Line 6 between the rise axis and the continental margin (HF-10, 11, 14, and 16).

\section{Cores}

Two gravity cores were attempted during the site survey, one at Site 482 and another near the west end of Line 6 . The first core (GC-06), which was located near one of our OBS stations, penetrated 6 meters and returned a sample of gray green mud 1.6 meters long. The second gravity core station (GC-15) showed more than 6 meters of penetration but returned with an empty liner. The core weights, however, were covered with a very fine-grained ooze, suggesting that the sample may have washed out on the way to the surface. 


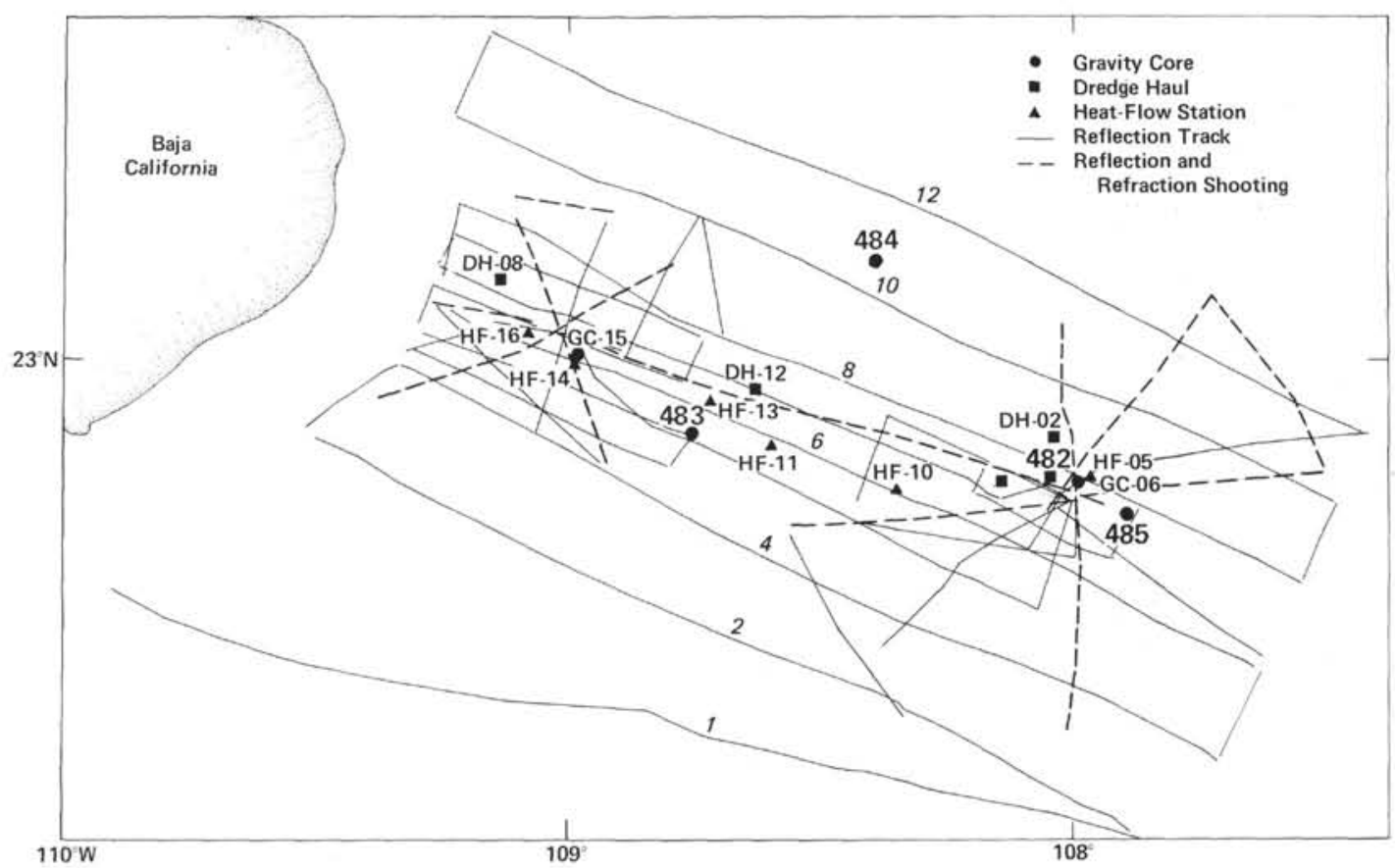

Figure 2. Survey lines and locations of sampling stations. (Circles show locations of sites drilled on Leg 65.)

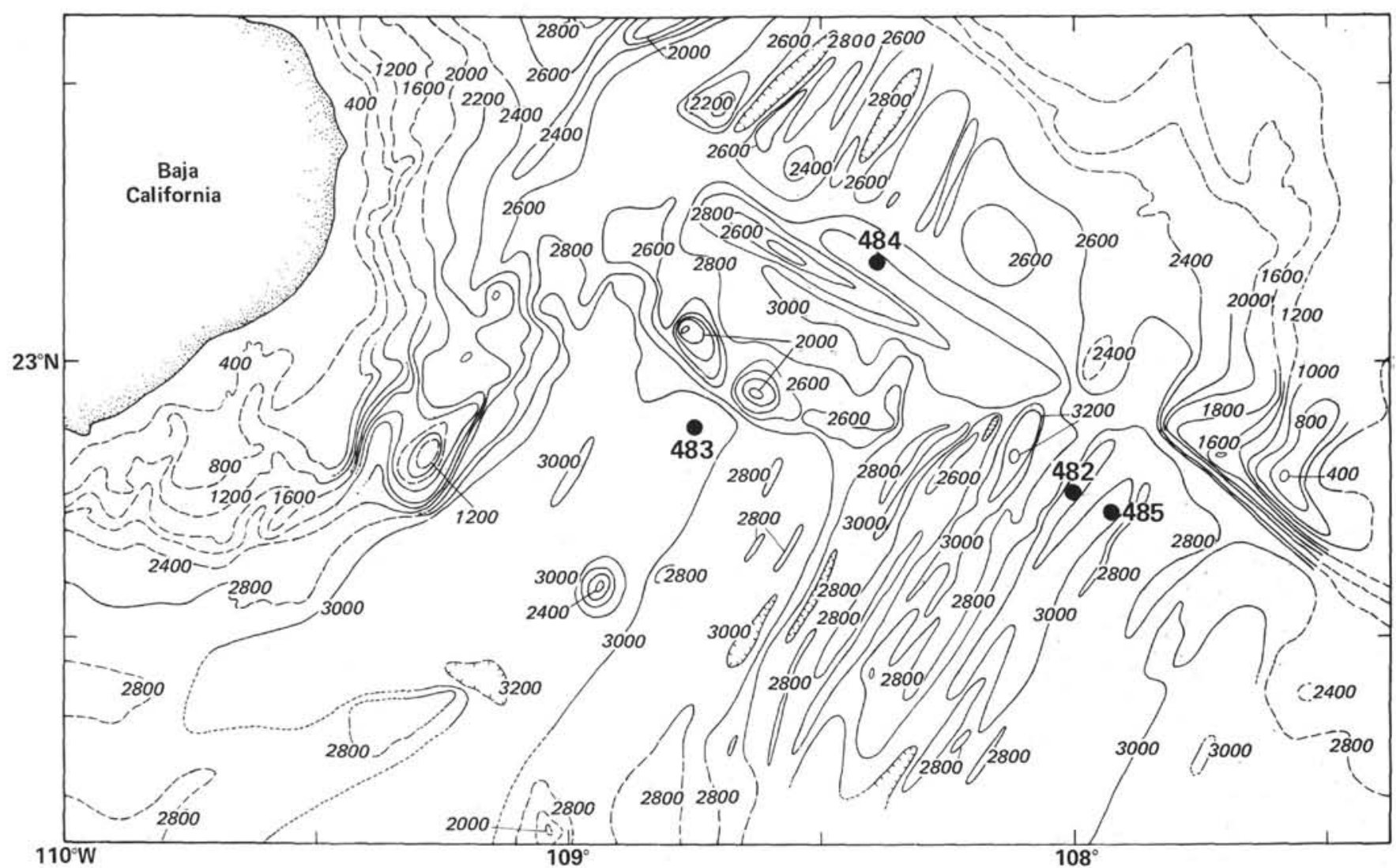

Figure 3. Bathymetric chart of survey area. (Data used to compile this chart comes from this study [TT-099, June 1975] and prior work by others. Depths in uncorrected meters. Solid circles show locations of sites drilled on Leg 65.) 

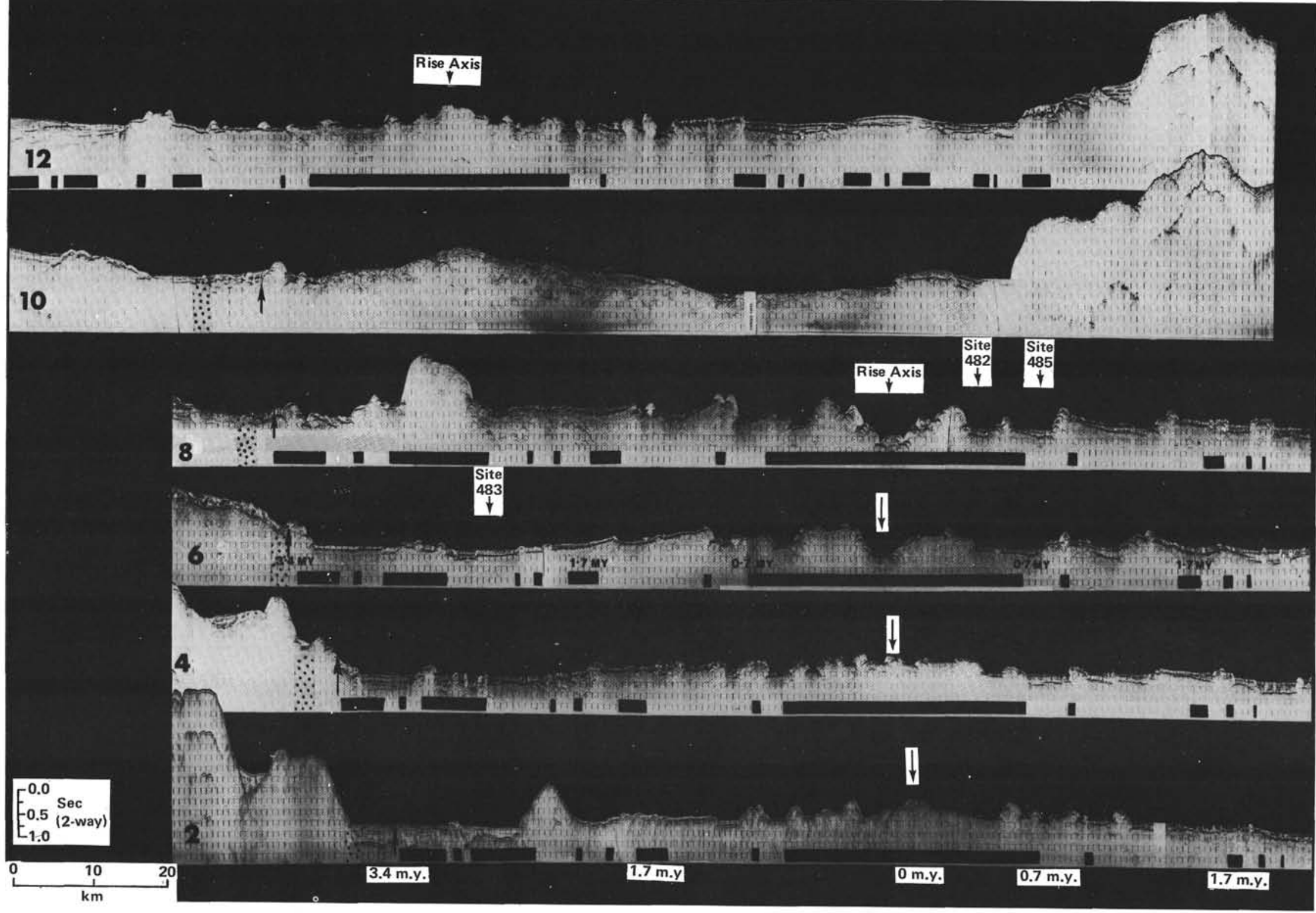

Figure 4. Seismic reflection profiles perpendicular to the rise axis, showing the rise axis, heat-flow values in $\mu \mathrm{cal} / \mathrm{cm} \mathrm{s}$, estimated magnetic reversal boundaries and ages (dark stripes represent periods of normal polarity), and our estimate of where the line of initial rifting of Baja is located (speckled zone). The Tamayo Fracture Zone cuts across Line 10 at a shallow angle, and the offset rise crest is seen again on Line 12. The vertical arrow at the margin indicates the position of the $3.4 \mathrm{~m} . \mathrm{y}$. isochron. 


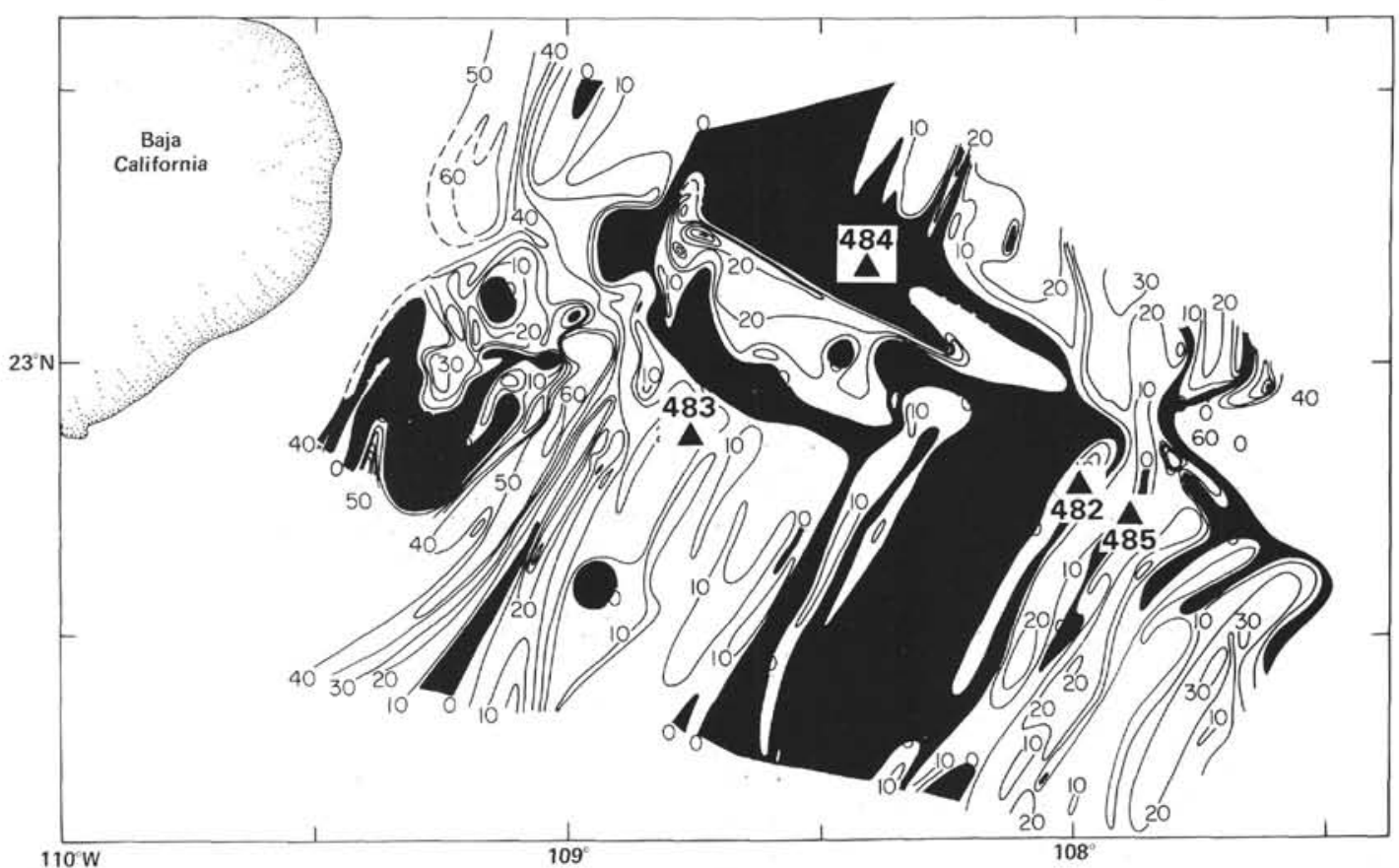

Figure 5. Sediment thickness determined by seismic reflection profiling. Thicknesses given in milliseconds of travel time (two-way). (Dark area shows area of zero sediment accumulation. Triangles show locations of sites drilled on Leg 65.)

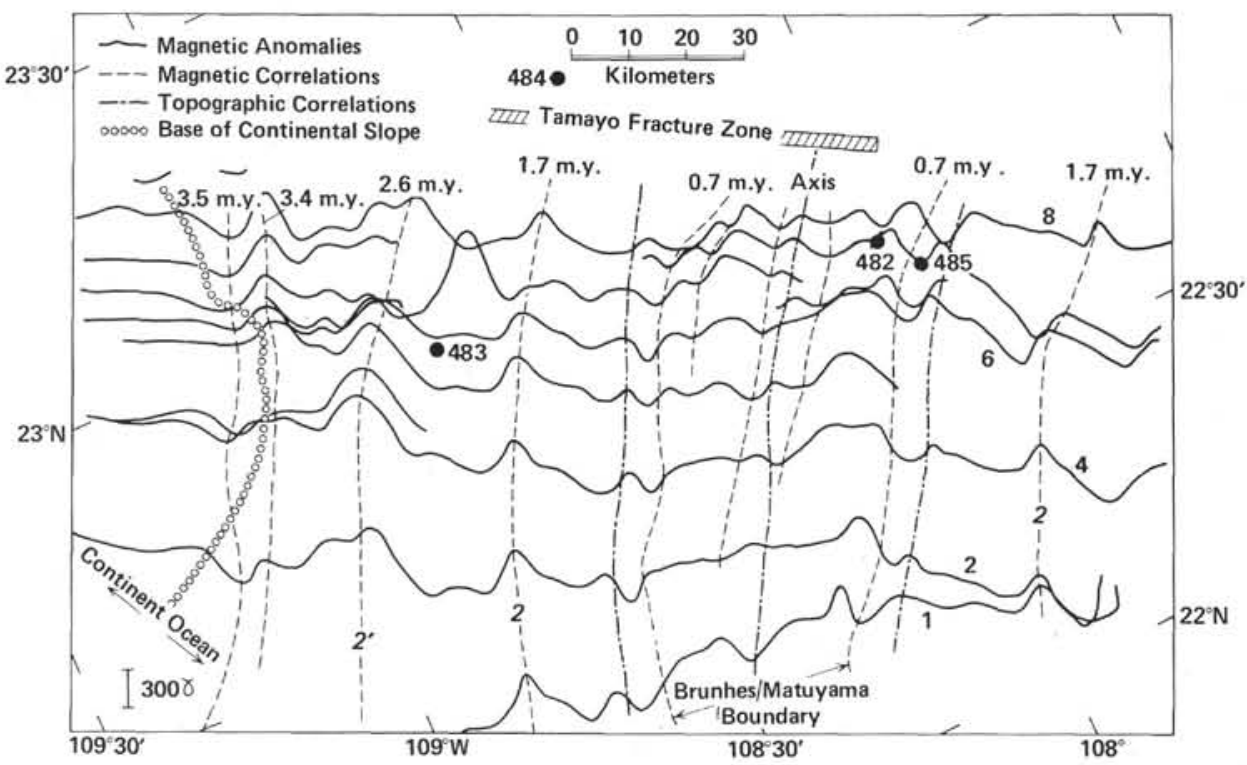

Figure 6. Magnetic anomaly profiles (not rotated to the pole) plotted along the track lines shown in Figure 2. Also shown are correlations of magnetic anomalies and topographic lineations. The rise axis and the base of the Baja California continental slope are also shown. (Circles show locations of sites drilled on Leg 65.)

\section{Dredge Hauls}

Five dredge hauls were made on the cruise at the various locations shown in Figure 2. Three hauls (DH$01,02,09)$ were made in the vicinity of the rise axis within Anomaly 1 and another (DH-08) was made on the continental slope. The fifth dredge haul (DH-12) was made on a seamount west of the rise axis $\left(22^{\circ} 58^{\prime} \mathrm{N}\right.$, $\left.108^{\circ} 39^{\prime} \mathrm{W}\right)$. The locations and major rock assemblages found in the five hauls are given in Table 2. All of the specimens examined were basalts or sediments.

Of the three dredge hauls made near Site 482, the first (DH-01) was made on the flank of the east ridge of the rise axis. A second haul (DH-02) was made along the summit of the east ridge, and the third (DH-09) was made along the floor of the median valley of the rise 
Table 1. Heat-flow stations in the mouth of the Gulf of California.

\begin{tabular}{lccccccrrr}
\hline Station & Latitude & Longitude & $\begin{array}{c}\text { Gradient } \\
\left({ }^{\circ} \mathrm{C} / \mathrm{m}\right)\end{array}$ & $\begin{array}{c}\text { Conductivity } \\
\left(\mathrm{cal} /{ }^{\circ} \mathrm{C} \mathrm{cm} \mathrm{s}\right)\end{array}$ & $\begin{array}{c}\text { Heat Flow } \\
\left(\mu \mathrm{cal} / \mathrm{cm}^{2} \mathrm{~s}\right)\end{array}$ & $\begin{array}{c}\text { Bottom } \\
\text { Water } \\
\text { Temperature } \\
\left({ }^{\circ} \mathrm{C}\right)\end{array}$ & $\begin{array}{c}\text { Sediment } \\
\text { Thickness } \\
(\mathrm{m})\end{array}$ & $\begin{array}{c}\text { Water } \\
\text { Depth } \\
(\mathrm{m})\end{array}$ & $\begin{array}{c}\text { Basement } \\
\text { Temperature } \\
\left({ }^{\circ} \mathrm{C}\right)\end{array}$ \\
\hline HF-05 & $22^{\circ} 46.8^{\prime}$ & $107^{\circ} 58.5^{\prime}$ & 0.647 & $1.82 \times 10^{-3 a}$ & $11.78 \pm 0.4$ & 1.670 & 167 & 2948 & $110^{\circ}$ \\
HF-10 & $22^{\circ} 45.5^{\prime}$ & $108^{\circ} 21.0^{\prime}$ & 0.391 & $1.82 \times 10^{-3}$ & $7.12 \pm 0.3$ & $1.610^{\mathrm{b}}$ & 62 & 2904 & $26^{\circ}$ \\
HF-11 & $22^{\circ} 50.6^{\prime}$ & $108^{\circ} 35.7^{\prime}$ & 0.344 & $1.83 \times 10^{-3}$ & $6.30 \pm 0.4$ & 1.578 & 73 & 2845 & $27^{\circ}$ \\
HF-13 & $22^{\circ} 55.5^{\prime}$ & $108^{\circ} 42.9^{\prime}$ & 0.267 & $2.01 \times 10^{-3}$ & $5.37 \pm 0.4$ & 1.539 & 125 & 3005 & $35^{\circ}$ \\
HF-14 & $22^{\circ} 59.5^{\prime}$ & $108^{\circ} 59.2^{\prime}$ & 0.100 & $2.31 \times 10^{-3}$ & $2.31 \pm 0.5$ & $1.533^{\mathrm{b}}$ & $>570$ & 2954 & - \\
HF-16 & $23^{\circ} 02.7^{\prime}$ & $109^{\circ} 04.7^{\prime}$ & 0.267 & $1.98 \times 10^{-3}$ & $5.29 \pm 0.3$ & 1.643 & 220 & 2508 & $60^{\circ}$ \\
\hline
\end{tabular}

Note: Basement temperatures shown were calculated from the sediment thickness and the measured gradient. Errors in the heat-flow values are estimated.

a Conductivity assumed.

b Water temperature was warmer than sediment.

Table 2. Summary of dredge hauls with a brief description of rock assemblages found.

\begin{tabular}{|c|c|c|c|}
\hline Station & Latitude & Longitude & Samples \\
\hline DH-01 & $22^{\circ} 47^{\prime} \mathrm{N}$ & $108^{\circ} 3^{\prime} \mathrm{W}$ & Fresh basalts with glassy margins on pillow surfaces. \\
\hline DH-02 & $22^{\circ} 51^{\prime} \mathrm{N}$ & $108^{\circ} 2^{\prime} \mathrm{W}$ & $\begin{array}{l}\text { Basalts with thick glass margins, some devitrification } \\
\text { and palagonite. }\end{array}$ \\
\hline DH-08 & $22^{\circ} 9^{\prime} \mathrm{N}$ & $109^{\circ} 8^{\prime} \mathrm{W}$ & $\begin{array}{l}\text { Basalts, some weathered, some vesicular. Dark, partly } \\
\text { consolidated sediments showing some evidence of } \\
\text { deformation. }\end{array}$ \\
\hline DH-09 & $22^{\circ} 47^{\prime} \mathrm{N}$ & $108^{\circ} 9^{\prime} \mathrm{W}$ & $\begin{array}{l}\text { Fresh basalt with glassy margins on pillow surfaces. } \\
\text { Some hydrothermally altered sediment? }\end{array}$ \\
\hline DH-12 & $22^{\circ} 57^{\prime} \mathrm{N}$ & $108^{\circ} 39^{\prime} \mathrm{W}$ & $\begin{array}{l}\text { Basalt with glassy margins, some vesicles. Breccia com- } \\
\text { posed of mud and volcanic fragments. Loosely } \\
\text { consolidated sediments. }\end{array}$ \\
\hline
\end{tabular}

axis. All three dredge hauls returned fresh to slightly weathered basalts, many with glassy margins up to onehalf $\mathrm{cm}$ thick. The hauls in the median valley and on the flank of the east ridge gave very similar samples with fresh glassy pillow structures. The rocks from the summit of the ridge, however, were different. Those rocks were more ropey in nature, with thick (up to $1 \mathrm{~cm}$ ) glass margins coated with manganese and showing some devitrification and palagonitization.

The dredge haul on the continental margin returned both basalt and sedimentary rocks. Some of the basalts recovered were quite weathered, while others were fresh and vesicular. The sedimentary rocks were composed of dark silty clay with light interbedded turbidites. They ranged from loosely to well consolidated and some showed evidence of deformation.

The dredge haul on the seamount also returned sediments and basalts. The sediments were partially consolidated and included a breccia of basalt fragments (some quite glassy) and mud. The basalts were quite fresh with some glass; several samples contained vesicles.

\section{Seismology}

Both ocean-bottom seismometers and telemetering buoys were used for refraction studies-the lines shot to these instruments are shown in Figure 2. In addition to the explosion sources, numerous earthquakes were recorded. In fact, one event was sufficiently large to be felt on the ship and required our postponing shooting for several hours until the area had quieted down. The details of the experiment were reported by McClain and Lewis (1980).

\section{DISCUSSION}

\section{Magnetics}

The magnetic anomaly profiles taken during the site survey are shown in Figure 6, together with correlations between anomalies and the ages of the anomalies (from Cox, 1969). Figure 6 also shows the correlation of linear topographic features in the survey area. From these data we find an average half-spreading rate of $2.7 \mathrm{~cm} / \mathrm{y}$. for the last $3.5 \mathrm{~m} . \mathrm{y}$.

In the rise axis region, the transition from an axial topographic high to an axial valley is accompanied by a distinct change in the style of the magnetic anomaly. A rather broad axial magnetic low within the central anomaly on Line 1 south of the valley is replaced by a series of narrow highs and lows as one proceeds toward the Tamayo Fracture Zone.

Toward the continental margin of Baja California, there is a well-defined magnetic lineation on 3.5-m.y.old crust that cuts across the topographic expression of the ocean/continent boundary. A careful examination of the topography in the area shows a small ridge with the same lineation. To the west of this line, the magnetic anomalies die out under continental material. We believe this lineation at 3.5 m.y. marks the rupture line where Baja California was rafted away from the mainland. This age and interpretation are similar to that of 
Larsen (1972). It is interesting to note that the rupture line starts out in oceanic crust on Line 2, cuts across the tip of Baja California on Lines 4 and 6, and extends away from the present bathymetrically defined margin on Lines 8 and 10 . The rupture line as marked by the topography seems to extend to Line 10 before being cut off by the Tamayo Fracture Zone (Fig. 6). As Larsen (1972) has pointed out, prior to 3.5 m.y., the East Pacific Rise was probably truncated by a fracture zone on the seaward side of Baja California. It is interesting to compare this rupture line with dredge haul results. Normark and Curray (1968) dredged granitic rocks off Cabrillo seamount, which is actually part of the continental margin immediately to the west of the rupture line indicated on Line 2 in Figure 4. Our dredge haul DH-08, which was just north and east of the rupture line shown on Line 6, returned mostly basalts and sedimentary rocks. Thus, the dredge hauls support our interpretation of the magnetic data and indicate that one would expect basaltic basement to the east of the rupture line and possibly granitic material to the west.

Another interesting feature of the magnetic data (Fig. 6) is that the anomalies do not form straight lines but seem to meander as if the spreading rate changed irregularly with time and distance along the ridge. This implies either that the plates are not rigid, which seems unreasonable, or that the injection zone in the axial region does not lie on a fixed straight line but migrates in time within some zone or finite width near the axis, giving the apparent asymmetric spreading observed.

To locate reversal boundaries, the magnetic anomalies on Profiles 2, 4, 6, 8, 10, and 12 were rotated to the pole using Fourier transform methods (Blakely and Cox, 1972) and compared with synthetic anomalies produced by upward continuation of the anomalies associated with a model having positively and negatively magnetized blocks corresponding to the time scale of Cox (1969). It was found that a constant spreading rate would not satisfy all of the profiles, so a varying rate was used to fit individual lines. This of course is probably the manifestation of a meandering spreading center rather than of varying spreading rates. The reversal boundaries found from this procedure are shown as bars in Figure 4. Inversion of these magnetic anomalies to obtain the magnetization and a comparison of this magnetization with that of dredged rocks is discussed by Hanley et al. (this volume).

\section{Bathymetry}

Probably the most interesting feature of the area is the axial valley at the northern end of the rise where it intersects the Tamayo Transform Zone (Fig. 4). The valley is up to $1 \mathrm{~km}$ deep and $17 \mathrm{~km}$ wide. It changes to a normal axial high about $50 \mathrm{~km}$ south of the Tamayo Fracture Zone and is not observed on the offset continuation of the axis north of the fracture zone. Refraction data (McClain and Lewis, 1980) indicate that the rift valley may be underlain by thin crust.

Another striking feature of the topography is the remarkable symmetry of structures across the axis. A sequence of linear sediment ponds, parallel to the rise, can be clearly correlated across the axis (Lines 4,6 , and 8 in Fig. 4). Lewis (1979) has argued that the symmetry in these data suggest periodicities in the rate of volcanism.

Rift valleys are unusual on the East Pacific Rise, but are observed on slower spreading segments of the ridge. Atwater and Mudie $(1968,1973)$ describe in detail the block faulted nature of the axial rift on the Gorda Rise. The Juan de Fuca Ridge has a rift valley or valleys at its northern end where it intersects the Savanco Ridge (McManus et al., 1972). As in the region discussed here, the rift dies out to the south and is not observed north of the fracture (Davis and Lister, 1977).

In general, the presence of a rift valley has been associated with slow spreading (e.g., Menard, 1967; Sleep and Biehler, 1970). Certainly, the half-spreading rate in the Gulf of California $(2.7 \mathrm{~cm} / \mathrm{y}$.) does not contradict this relationship (Sleep, personal communication). However, we observe no systematic increase in the spreading rate to the south and yet the rift dies out. Obviously another factor must be important. Sleep and Biehler (1970) state that one expects a rift at fracture-rise intersections as a consequence of fluid dynamic considerations. Contrary to their predictions, we only observe the rift on the southern side of the Tamayo Fracture Zone. The spreading rate and the presence of a fracture zone are probably important factors in the formation of rift valleys, but the asymmetry observed here suggests that other unknown factors are also involved.

\section{Sediments}

The sediments which fill the linear valleys generally increase in thickness away from the axis (Figs. 4 and 5). At Site 482 , the $P$ and $S$ wave velocities were low, 1.5 and $0.14 \mathrm{~km} / \mathrm{s}$, respectively, yielding a true sediment thickness of about 150 meters (McClain and Lewis, 1980). The thickest sediment accumulation is found along the continental margin at the base of the continental slope and has a thickness of at least $0.5 \mathrm{~s}$ (two-way travel time).

\section{Heat Flow}

As indicated previously, the results of the six heatflow stations are shown in Table 1 . The values obtained range from $11.78 \mu \mathrm{cal} / \mathrm{cm}^{2} \mathrm{~s}$ to $2.31 \mu \mathrm{cal} / \mathrm{cm}^{2} \mathrm{~s}$ and follow a trend of decreasing heat flow with age (Lister, 1972: Sclater and Francheteau, 1970). The interpretation of these heat-flow results in combination with the downhole temperatures and thermal conductivities measured on Leg 65 are given by Lewis (this volume).

\section{Seismology}

The results of the seismic refraction studies conducted at the spreading center have been reported in detail by McClain and Lewis (1980), and only the principal conclusions are presented here. From a line on the east side of the axis running oblique to the axis a detailed crustal velocity profile was obtained. Both traveltime inversion and waveform analysis using synthetic seismograms were used to obtain the velocity profile. These results are shown in Figure 7. The upper crustal velocity should pertain directly to the drilling results at 


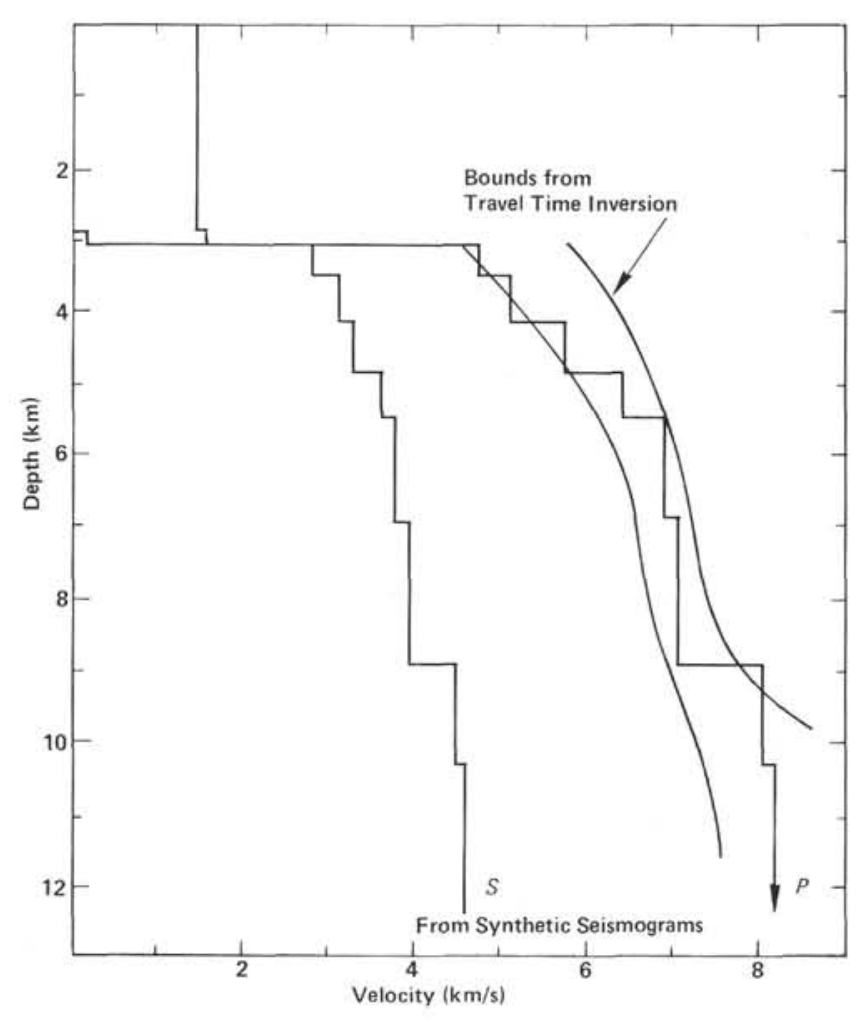

Figure 7. Velocity vs. depth profiles applicable to the crust under Sites 482 and 485.
Site 482 since the site was within a kilometer or two of the OBS sites. The lower crustal velocities probably pertain to an area older than the drill site since the line was oblique to the axis. The upper mantle velocity on this line was found to be $8.0 \mathrm{~km} / \mathrm{s}$, which is typical of older crustal sites and does not indicate a high temperature regime.

The results across the rise axis were modeled using two-dimensional ray tracing techniques, and a model which satisfies the travel times is shown in Figure 8 (McClain and Lewis, 1980). This model has a low-velocity zone in the crust under the axis which could be caused by a zone of partial melting.

\section{CONCLUSIONS}

The principal results from this survey were the identification of an axial valley on the East Pacific Rise south of the Tamayo Fracture Zone, the mapping of sediment thickness near the spreading axis, and the determination of lithospheric acoustic velocities under and adjacent to the axis. Subsequent to this study, more detailed bathymetric work in the area was undertaken by MacDonald (1979) using a deep-towed system, and by Rangin (this volume) using the French multibeam system. In addition, Fox (personal communication) has undertaken detailed dredging. The data from these studies will no doubt elucidate in greater detail the geologic processes operative in the area.
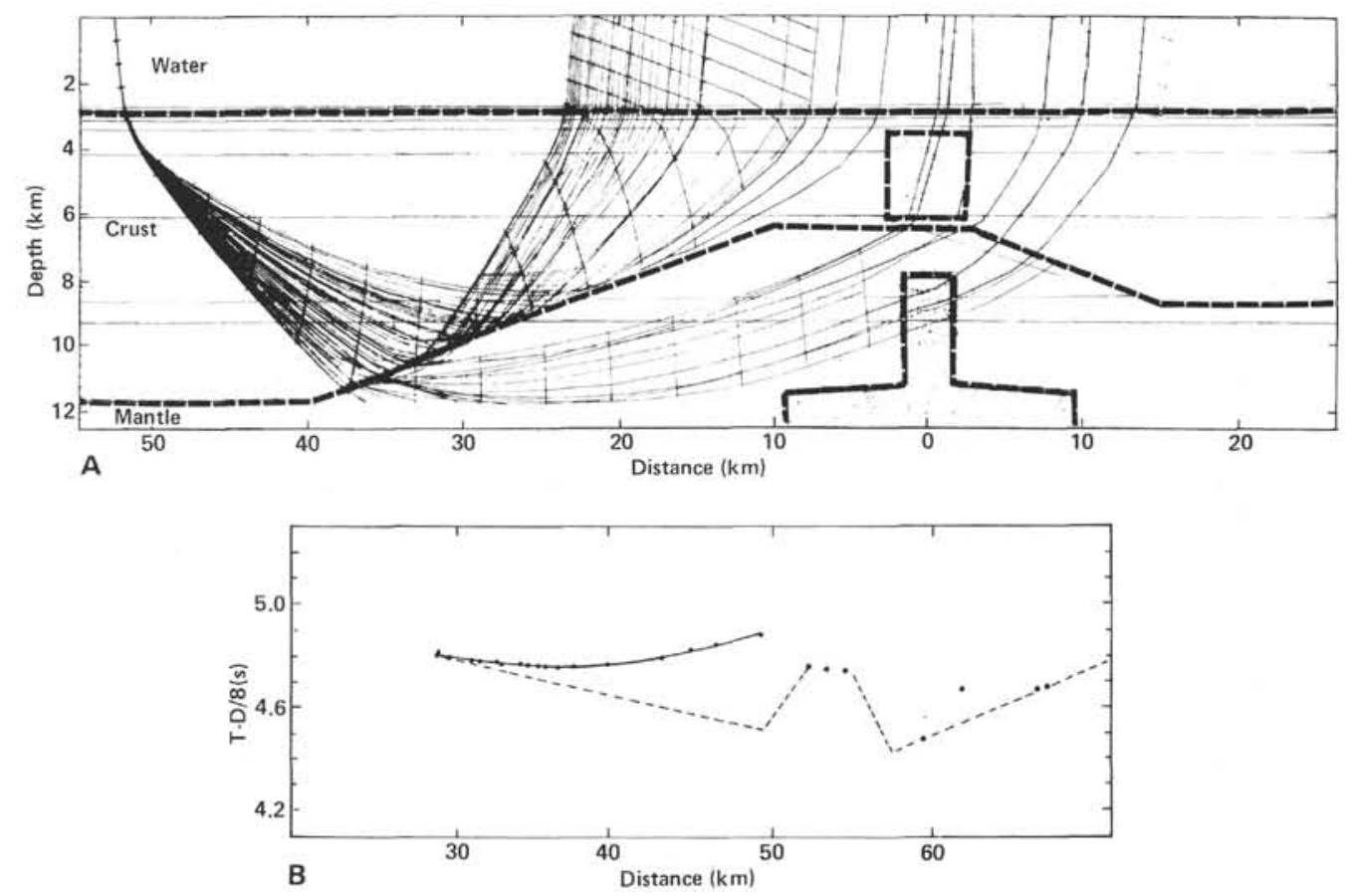

Figure 8. A. Crustal model across the rise axis obtained by fitting travel times from shots across the axis to a telemetering buoy on the west side of the spreading center (after McClain and Lewis, 1980). Stippled area shows position of low-velocity zone. B. Comparison of computed travel times (dots) and observed travel times (dashed and solid lines) for the model in Figure 8A. 
The drilling results on Leg 65 served to confirm the accuracy of the heat-flow measurements taken during the survey (Lewis, this volume) and to clarify the interpretation of the seismic velocities in the uppermost crust (Christensen and Lewis, this volume).

Seyeral perplexing questions were identified by this study which remain unanswered, however. Why, for example, is there an axial valley south of the Tamayo Fracture Zone but not north of it? While the mechanism of Sleep and Biehler (1970) has considerable merit, it does not adequately explain this area, suggesting that other, unidentified processes are responsible. Why does the crust thicken with age? As the Leg 65 drilling has shown, plate accretion close to a source of sediments provides a specialized geologic environment which gives rise to interlayering of basalt flows and sediments. This provides a relatively impermeable cap to hydrothermal convection in the crust, which in turn can alter the rate of crustal cooling relative to areas with little sediment supply. How does this influence metamorphic processes and crustal aging? In summary, the survey conducted in the mouth of the Gulf of California was successful in identifying the drill sites for Leg 65 , but it ultimately raised as many geologic problems as it solved.

\section{ACKNOWLEDGMENTS}

This work was supported by a contract with Columbia University as a contribution to the International Phase of Ocean Drilling of the Deep Sea Drilling Project. We thank Dr. Clive Lister for the use of his heat-flow and acoustic-profiling instruments and Carol Heitman for his assistance in analyzing the data. We also appreciate the help received by students from the Universidad Nacional Autónoma de México and the captain and crew of the Thomas G. Thompson.

George Sharman of the Scripps institution of Oceanography kindly sent us copies of unpublished reflection profiles from the Davis 1967 and 1968 surveys and the 1972 Hypogene survey. These were very helpful in planning the cruise and in constructing detailed bathymetric and sediment thickness charts.

\section{REFERENCES}

Atwater, T. M., and Mudie, J. D., 1968. Block faulting on the Gorda Rise. Science. 159:729-731.
1973. A detailed near bottom geophysical study of the Gorda Rise. J. Geophys. Res., 78:8805-8686.

Blakely, R., and Cox, A., 1972. Identification of short polarity events by transforming marine magnetic anomalies to the pole. J. Geophys. Res., 77:4339-4349.

Cox, A., 1969. Geomagnetic reversals. Science 163:237-245.

Davis, E. E., and Lister, C.R.B., 1977. Tectonic structures on the Juan de Fuca Ridge. Geol. Soc. Am. Bull., 88:346-363.

Larsen, R. L., 1972. Bathymetry, magnetic anomalies, and plate tectonic history of the mouth of the Gulf of California. Geol. Soc. Am. Bull., 19:521-532.

Lewis, B. T. R., 1979. Periodicities in volcanism and longitudinal magma flow on the East Pacific Rise at $23^{\circ} \mathrm{N}$. Geophys. Res. Lett., 6(10):753-756.

Lister, C. R. B., 1970. Measurement of in situ sediment conductivity by means of a Bullard-type probe. Geophys. J. R. Astron. Soc., 19:521-532.

1972. On the thermal balance of a mid-ocean ridge. Geophys. J. R. Astron. Soc., 26:515-535.

McClain, J. S., and Lewis, B. T. R., 1980. A seismic experiment at the axis of the East Pacific Rise. Mar. Geol., 35:147-169.

Macdonald, K. C., Kastens, K., Spiess, F. N., and Miller, S. P., 1979. Deep tow studies of the Tamayo Transform Fault. Mar. Geophys. Res., 4:37-70.

McManus, D. A., Holmes, M. L., Carson, B., and Barr, S. M., 1972. Late Quaternary tectonics, northern end of the Juan de Fuca Ridge (Northwest Pacific). Mar. Geol., 12:141-164.

Menard, H. W., 1967. Seafloor spreading, topography and the second layer. Science, 157:923-924.

Molnar, P., 1973. Fault plane solutions of earthquakes and directions of motion in the Gulf of California and on the Rivera Fracture Zone. Geol. Soc. Am. Bull., 84:1651-1658.

Moore, D. G., 1973. Plate-edge deformation and crustal growth, Gulf of California structural province. Geol. Soc. Am. Bull., 84: 1883-1906.

Normark, W. R., and Curray, J. R., 1968. Geology and structure of the tip of Baja California, Mexico. Geol. Soc. Am. Bull., 79: $1589-1600$.

Sclater, J. G., and Francheteau, J., 1970. The implications of terrestrial heat flow observations on current tectonic and geochemical models of the crust and upper mantle of the earth. Geophys. J., 20:509-542.

Sleep, N. H., and Biehler, S., 1970. Topography and tectonics at the intersection of fracture zones with central rifts. J. Geophys. Res., $75: 2748-2752$.

van Andel, Tj. H., and Shor, G. G. Jr. (Eds.). 1964. Marine Geology of the Gulf of California: Tulsa (Am. Assn. Petroleum Geologists, Memoir 3). 